\title{
Effect of UV Irradiation on Macromolecular Synthesis and Colony Formation in Bacteroides fragilis
}

\author{
By J. PETRA SCHUMANN, DAVID T. JONES AND \\ DAVID R. WOODS* \\ CSIR Applied Microbial Genetics Research Unit, Department of Microbiology, \\ University of Cape Town, Rondebosch 7700, South Africa
}

(Received 7 September 1983; revised 1 December 1983)

\begin{abstract}
Irradiation of Bacteroides fragilis cells with far-UV light resulted in the immediate, rapid and extensive degradation of DNA which continued for 40 to $60 \mathrm{~min}$ after irradiation. During the degradation phase, DNA synthesis was decreased but was never totally inhibited. DNA degradation after irradiation was inhibited by chloramphenicol and caffeine. DNA synthesis in irradiated cells was reduced by chloramphenicol but resumed after $100 \mathrm{~min}$ at the same exponential rate as in irradiated cells without chloramphenicol. Irradiated cells continued to synthesize DNA for $40 \mathrm{~min}$ in the presence of caffeine but after this time DNA synthesis was completely inhibited and never recovered. RNA and protein synthesis were decreased by UV irradiation and the degree of inhibition was proportional to the UV dose. Colony formation was not affected immediately by UV irradiation and continued for a dose-dependent period before inhibition. There was an inverse relationship between UV dose and inhibition of colony formation which occurred sooner in cells irradiated with lower doses of UV light. The characteristics of DNA synthesis in $B$. fragilis cells after UV irradiation differ from those in wild-type Escherichia coli cells, where DNA synthesis is stopped immediately by UV irradiation, but resemble those in $E$. coli rec $A$ mutant cells where extensive degradation occurs following UV irradiation.
\end{abstract}

\section{INTRODUCTION}

DNA synthesis in Escherichia coli and a number of other aerobic bacteria is inhibited by farUV radiation (254 nm) (Kelner, 1953; Swenson \& Setlow, 1966; Swenson, 1976; Trgovcevic et al., 1980). Inhibition of DNA synthesis occurs almost immediately. After a dose-dependent lag it recovers and proceeds at the same rate as in unirradiated cells. Photoreactivation largely relieves this inhibition, indicating that the inhibition is caused primarily by pyrimidine dimers (Hall \& Mount, 1981). RecA mutants of E. coli extensively degrade their DNA after UV irradiation (Clark, 1973). Most of this degradation is due to the recBC DNAase (Willetts \& Clark, 1969; Satta et al., 1979), and Williams et al. (1981) showed that purified rec $A^{+}$protein inhibited the endonuclease and exonuclease activities of $\operatorname{rec} B C$ DNAase on single-stranded DNA. DNA synthesis after UV irradiation was studied by Trgovcevic et al. (1980) in wild-type, $u \operatorname{co} A, \operatorname{rec} B, \operatorname{rec} A-\operatorname{rec} B$ and $\operatorname{rec} A E$. coli strains and it was shown that the inhibition of DNA synthesis after UV irradiation depended on the rec $A$ gene being functional. In $E$. coli the UVinducible rec $A$ protein has a molecular weight of 37800 (Horii et al., 1980; Sancar et al., 1980).

Irradiation of Bacteroides fragilis cells under anaerobic conditions results in the induction of a new 95000 molecular weight protein and the increased synthesis of two proteins with molecular weights of 70000 and 90000 (Schumann et al., 1982). The induction of a 37000 to 40000 molecular weight protein by UV irradiation was not detected in $B$. fragilis. As the far-UVinduced systems in B. fragilis (Jones et al., 1980; Jones \& Woods, 1981; Slade et al., 1981; Schumann et al., 1982) seem to differ in certain respects from those in $E$. coli, we investigated the effect of UV irradiation on macromolecular synthesis and colony formation under anaerobic conditions. This appears to be the first report of the effect in an obligate anaerobe. 


\section{METHODS}

Bacteria and media. These studies were carried out on a $B$. fragilis strain $(\mathrm{Bf}-2)$ which has been used in previous studies on far-UV irradiation (Jones et al., 1980; Jones \& Woods, 1981; Slade et al., 1981, 1983; Schumann et al., 1982). Brain heart infusion broth and agar, supplemented with haemin, menadione and cysteine (Holdeman \& Moore, 1972) were used for bacterial propagation at $37^{\circ} \mathrm{C}$. Pre-reduced one-quarter-strength Ringer solution was used as a dilution buffer (Jones \& Woods, 1981). Irradiation and radioactive labelling of the cells were done in a defined minimal medium (Varel \& Bryant, 1974). The doubling time during exponential growth of $B$. fragilis in this minimal medium was $62 \mathrm{~min}$ at $37^{\circ} \mathrm{C}$. All manipulations were carried out under stringent anaerobic conditions in an anaerobic glove cabinet (Forma Scientific, Marietta, Ohio, USA).

$U V$ irradiation. Overnight cultures of $B$. fragilis cells in brain heart infusion broth were diluted 100 -fold in minimal medium and reincubated until the cultures reached a turbidity of 0.2 at $600 \mathrm{~nm}\left(1 \times 10^{8}\right.$ to $2 \times$ $10^{8}$ c.f.u. $\left.\mathrm{ml}^{-1}\right)$. Samples $(9 \mathrm{ml})$ of the cultures were irradiated in open glass Petri dishes with a Fluotest Piccolo Hanau Quartz germicidal lamp which emitted the majority of its output at $254 \mathrm{~nm}$. The dose-rate was measured with a Blak-Ray UV meter (model J-225; UV Products Inc., San Gabriel, Calif., USA) and samples were irradiated at a flux of $1.0 \mathrm{~J} \mathrm{~m}^{-2} \mathrm{~s}^{-1}$. Survival curves of bacteria irradiated with increasing doses were determined, and labelling experiments were carried out with cultures which were irradiated to different survival levels.

$D N A, R N A$ and protein synthesis. DNA synthesis was determined by the incorporation of $\left[2{ }^{14} \mathrm{C}\right]$ thymidine $\left(4 \mu \mathrm{Ci} \mathrm{ml} l^{-1} ; 1 \mu \mathrm{Ci}=37 \mathrm{kBq}\right)$ or $\left[\right.$ methyl $\left.{ }^{-3} \mathrm{H}\right]$ thymidine $\left(10 \mu \mathrm{Ci} \mathrm{ml}^{-1}\right)$, RNA synthesis by the incorporation of $\left[5,6{ }^{-3} \mathrm{H}\right]$ uracil $\left(15 \mu \mathrm{Ci} \mathrm{ml}^{-1}\right)$, and protein synthesis by the incorporation of $\left.\mathrm{L}-{ }^{35} \mathrm{~S}\right] \mathrm{methionine}\left(20 \mu \mathrm{Ci} \mathrm{ml}^{-1}\right)$ into cold TCA precipitable cellular material. The labelled chemicals were supplied by Amersham. The final concentrations of thymidine, uracil and methionine were 7,15 and $25 \mu \mathrm{g} \mathrm{ml}^{-1}$ respectively, which were saturating for both uptake and incorporation over $240 \mathrm{~min}$.

The effect of UV irradiation on DNA, RNA and protein synthesis was determined in prelabelled and unlabelled cultures (Smith \& O'Leary, 1968: Setlow \& Setlow, 1970). In order to prelabel cells, overnight brain heart infusion broth cultures were inoculated into minimal medium and incubated until the cultures reached a turbidity of 0.15 at $600 \mathrm{~nm}$. The label was added and the cultures were reincubated, until a turbidity of 0.2 at $600 \mathrm{~nm}$ was reached, before irradiation with UV light (prelabelled cells). In experiments involving unlabelled cells, the label was added to the culture immediately after irradiation. For dual labelling experiments, the cells were prelabelled for $60 \mathrm{~min}$ with $\left[{ }^{14} \mathrm{C}\right]$ thymidine. The labelled cells were then harvested by centrifugation, resuspended in fresh minimal medium without label and incubated for a further $50 \mathrm{~min}$ before irradiation and the addition of $\left[{ }^{3} \mathrm{H}\right]$ thymidine.

Effect of chloramphenicol and caffeine on DNA synthesis. The effect of chloramphenicol $\left(5 \mu \mathrm{g} \mathrm{ml}^{-1}\right)$ and caffeine $\left(1 \mathrm{mg} \mathrm{ml}{ }^{-1}\right)$ on DNA synthesis after UV irradiation was determined with prelabelled and unlabelled cells. The inhibitors were not present during irradiation, but were added to minimal medium cultures immediately after irradiation. The minimal inhibitory concentrations of chloramphenicol and caffeine were $1 \mu \mathrm{g} \mathrm{ml}^{-1}$ and $2.5 \mathrm{mg} \mathrm{ml}^{-1}$, respectively.

Effect of $U V$ irradiation on colony formation. Exponential phase cells in minimal medium were irradiated with UV doses of $0,30,40,50$ or $70 \mathrm{~J} \mathrm{~m}^{-2}$ and reincubated at $37^{\circ} \mathrm{C}$ under anaerobic conditions. Colony formation was determined after different time intervals by plating on brain heart infusion agar.

\section{RESULTS}

\section{Effect of UV irradiation on DNA synthesis}

UV irradiation of $B$. fragilis cells prelabelled with $\left[{ }^{14} \mathrm{C}\right]$ thymidine resulted in an initial rapid net loss of label from the TCA precipitable fraction (Fig. 1). The DNA degradation phase was followed after approximately $60 \mathrm{~min}$ by the net synthesis of DNA. Dual labelling experiments were carried out to determine whether DNA synthesis was masked during the DNA degradation phase (Fig. 2). DNA synthesis was decreased after UV irradiation, but never totally inhibited. This DNA synthesis was masked in the prelabelling experiments by the phase of extensive DNA degradation immediately after exposure to UV irradiation. Degradation of prelabelled DNA continued for $40 \mathrm{~min}$ post-irradiation before reaching a plateau between 40 and $160 \mathrm{~min}$, when there was no net loss of $\left[{ }^{14} \mathrm{C}\right]$ thymidine from the DNA.

DNA synthesis was also determined in unlabelled cultures which were irradiated with increasing doses of UV light before the addition of $\left[{ }^{14} \mathrm{C}\right]$ thymidine. In these experiments DNA synthesis was measured by the net accumulation of label into TCA precipitable material. In unirradiated unlabelled $B$. fragilis cells exponential incorporation of $\left[{ }^{14} \mathrm{C}\right]$ thymidine similar to that in unirradiated prelabelled cells was observed $30 \mathrm{~min}$ after the addition of the label, which 


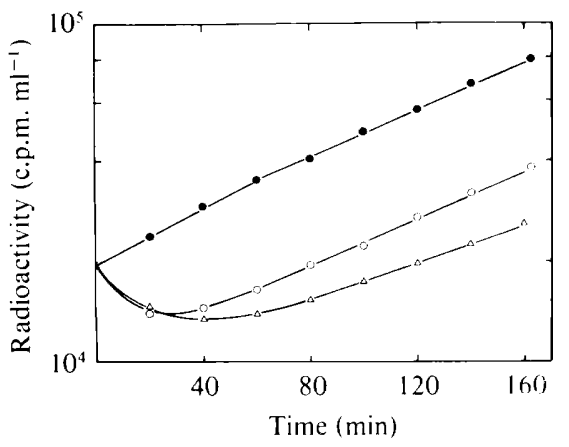

Fig. 1

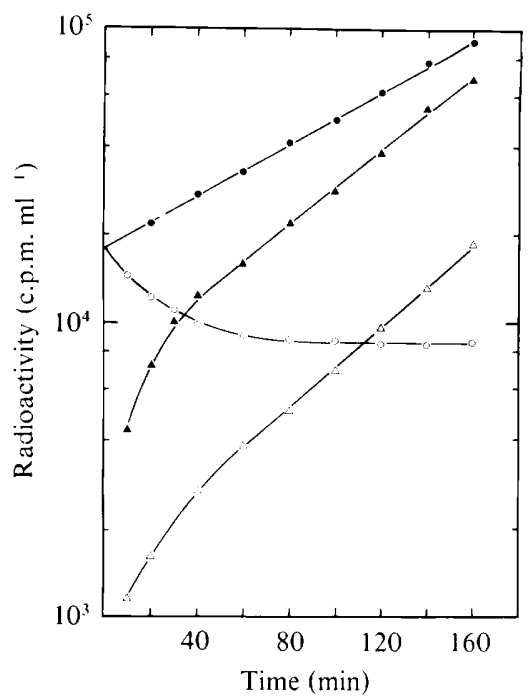

Fig. 2

Fig. 1. Effect of UV irradiation on DNA synthesis in prelabelled $B$. fragilis cells. The $\left[{ }^{14} \mathrm{C}\right]$ thymidine was added to the cells $60 \mathrm{~min}$ before irradiation. The cells were irradiated and reincubated in the presence of the label. Unirradiated control $(\mathbf{O})$; cells irradiated with UV doses of $50 \mathrm{~J} \mathrm{~m}^{-2}(11 \%$ survival) $(O)$ and $70 \mathrm{~J} \mathrm{~m}^{-2}(1 \cdot 2 \%$ survival) $(\triangle)$.

Fig. 2. Effect of UV irradiation on DNA synthesis in dual-labelled B. fragilis cells. Cells prelabelled with $\left[{ }^{14} \mathrm{C}\right]$ thymidine for $60 \mathrm{~min}$ were harvested by centrifugation, resuspended in fresh medium without label and incubated for a further $50 \mathrm{~min}$ before UV irradiation $\left(50 \mathrm{~J} \mathrm{~m}^{-2}, 11 \%\right.$ survival) and the addition of $\left[{ }^{3} \mathrm{H}\right]$ thymidine at time 0 . Uniriadiated prelabelled control reincubated in $\left[{ }^{14} \mathrm{C}\right]$ thymidine at time $0 \mathrm{~min}(\bigcirc)$. Irradiated cells with $(\triangle)$ and without $(\bigcirc)\left[{ }^{3} \mathrm{H}\right]$ thymidine added at the time of irradiation (time $0 \mathrm{~min}$ ). Unirradiated cells with $\left[{ }^{3} \mathrm{H}\right]$ thymidine added at time $0(\boldsymbol{\Delta})$.

indicated that pool equilibrium of the thymidine precursor in the prototrophic $B$. fragilis cells was attained within that $30 \mathrm{~min}$ period. DNA synthesis was reduced after UV irradiation and showed linear kinetics for a dose-dependent period (Fig. 3). At higher UV doses there was a longer period of linear DNA synthesis. DNA synthesis during this linear phase also decreased with increasing UV doses. After irradiation to different survival levels, DNA synthesis resumed in all the cultures at the same exponential rate with the exception of the $1 \cdot 2 \%$ survival culture. The time that elapsed before the resumption of exponential DNA synthesis was dosedependent.

\section{Effect of chloramphenicol and caffeine on DNA synthesis after $U V$ irradiation}

Experiments with prelabelled cells indicated that extensive degradation of DNA was inhibited by the addition of chloramphenicol immediately after UV irradiation (Fig. 4). In these prelabelled cells net DNA synthesis was detected 100 min after UV irradiation. Experiments with unlabelled cells showed that DNA synthesis after UV irradiation was markedly reduced by chloramphenicol but not inhibited completely. After $100 \mathrm{~min}$ DNA synthesis in chloramphenicol-treated irradiated cells resumed at the same exponential rate as that in irradiated cells without chloramphenicol. DNA synthesis in unirradiated cells was decreased by chloramphenicol and inhibited after $60 \mathrm{~min}$. Chloramphenicol $\left(5 \mu \mathrm{g} \mathrm{ml}^{-1}\right)$ inhibited protein synthesis immediately in unirradiated cells.

Caffeine treatment of prelabelled irradiated cells inhibited extensive DNA degradation immediately and DNA synthesis $40 \mathrm{~min}$ after UV irradiation (Fig. 5). DNA synthesis in unlabelled UV-irradiated cells was completely inhibited by caffeine $40 \mathrm{~min}$ after irradiation. Caffeine did not affect DNA synthesis in unirradiated cells. 


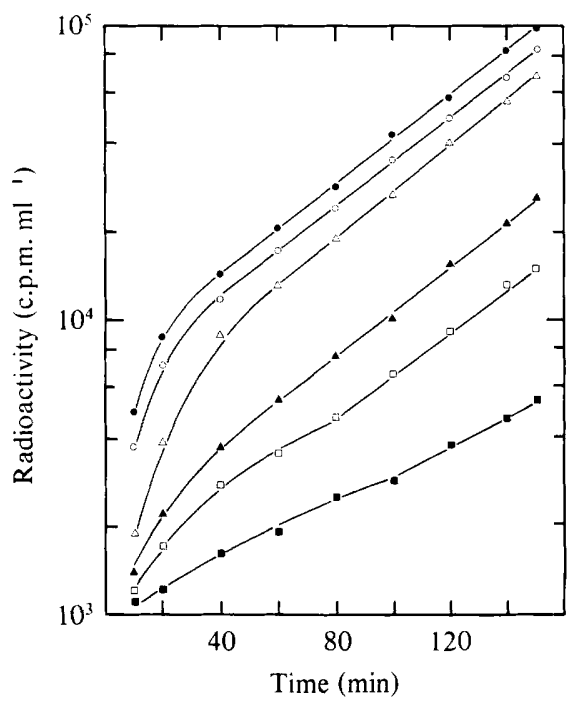

Fig. 3. Effect of increasing doses of UV irradiation on DNA synthesis in unlabelled $B$. fragilis cells. Exponential phase cells were irradiated and labelled with $\left[{ }^{14} \mathrm{C}\right]$ thymidine. Unirradiated control $(\boldsymbol{Q})$. Cells irradiated with UV doses of $\left(\mathrm{J} \mathrm{m}^{-2}\right): 20(86 \%$ survival $)(0) ; 30(62 \%$ survival $)(\triangle) ; 40(26 \%$ survival) $(\mathbf{\Lambda}) ; 50(11 \%$ survival $)(\square)$ and $70(1 \cdot 2 \%$ survival $)(\boldsymbol{\square})$.

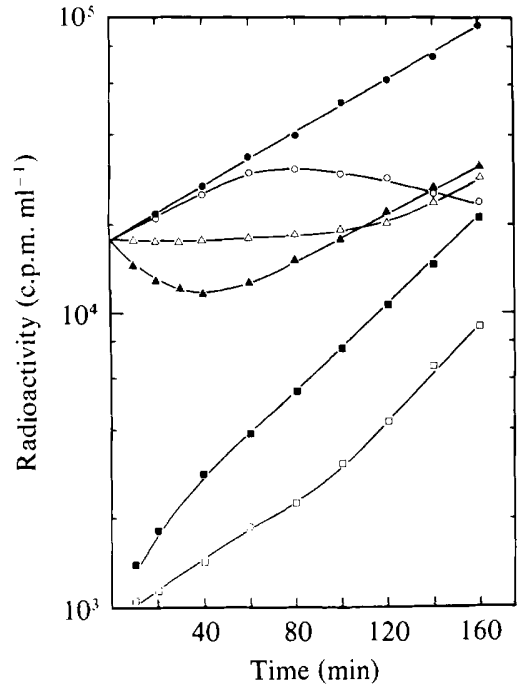

Fig. 4

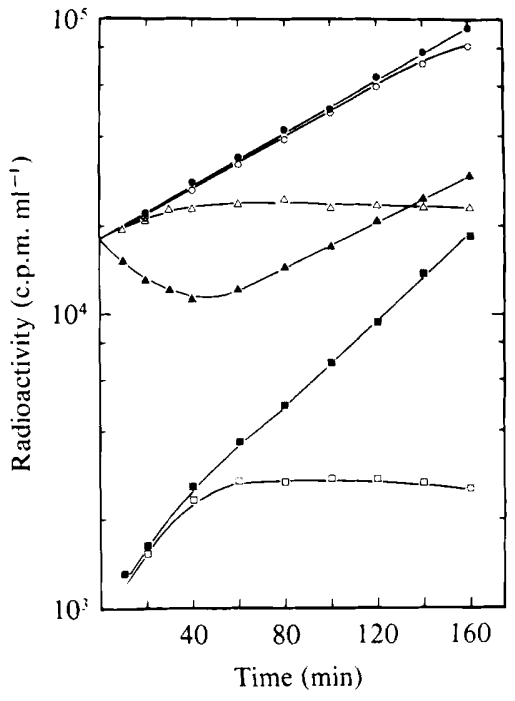

Fig. 5

Fig. 4. Effect of chloramphenicol on DNA synthesis after UV irradiation. Cells prelabelled with $\left[{ }^{14} \mathrm{C}\right]$ thymidine before UV irradiation with $(\Delta)$ and without $(\boldsymbol{\Delta})$ chloramphenicol. Cells irradiated and then labelled with $\left[{ }^{14} \mathrm{C}\right]$ thymidine with $(\square)$ and without $(\square)$ chloramphenicol. Unirradiated cells prelabelled with $\left[{ }^{14} \mathrm{C}\right]$ thymidine with $(O)$ and without $(\bigcirc)$ chloramphenicol. Cells were irradiated with a UV dose of $50 \mathrm{~J} \mathrm{~m}^{-2}$ (11\% survival).

Fig. 5. Effect of caffeine on DNA synthesis after UV irradiation. Cells prelabelled with $\left[{ }^{14} \mathrm{C}\right]$ thymidine before $\mathrm{UV}$ irradiation with $(\triangle)$ and without $(\boldsymbol{\Delta})$ caffeine. Cells irradiated and then labelled with $\left[{ }^{14} \mathrm{C}\right]$ thymidine with $(\square)$ and without $(\mathbf{D})$ caffeine. Unirradiated cells prelabelled with $\left[{ }^{14} \mathrm{C}\right]$ thymidine with $(O)$ and without $(\bigcirc)$ caffeine. Cells were irradiated with a UV dose of $50 \mathrm{~J} \mathrm{~m}^{-2}$ $(11 \%$ survival). 


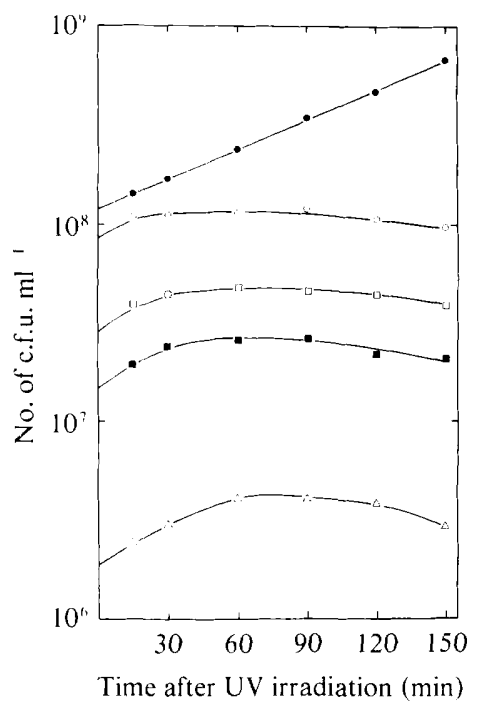

Fig. 6. Effect of UV irradiation on colony formation by B. fragilis cells under anaerobic conditions. Cells were irradiated with increasing doses of UV and samples were plated onto brain heart infusion agar at various times after irradiation. UV doses were $\left(\mathrm{J} \mathrm{m}^{-2}\right): 30(62 \%$ survival $)(0) ; 40(24 \%$ survival) $(\square) ; 50(12 \%$ survival) $(\square)$ and $70(1.5 \%$ survival) $(\Delta)$. Unirradiated control $(\bigcirc)$

\section{Effect of UV irradiation on RNA and protein synthesis}

UV irradiation of $B$. fragilis cells resulted in a dose-dependent decrease in RNA and protein synthesis. Protein synthesis was less sensitive than RNA synthesis to UV irradiation. After irradiation at $50 \mathrm{~J} \mathrm{~m}^{-2}(11 \%$ survival $)$ RNA synthesis was reduced by $42 \%$ compared with the unirradiated control and increased linearly for approximately $60 \mathrm{~min}$ before it resumed exponentially at a somewhat lower rate than in the unirradiated control. At the same dose protein synthesis was only reduced by $28 \%$ and continued in an exponential fashion. At $1.2 \%$ survival both RNA and protein synthesis were markedly reduced and showed linear kinetics until the end of the experiment (160 min).

\section{Effect of UV irradiation on colony formation}

The ability of $B$. fragilis to form colonies on agar medium was not affected immediately by UV irradiation (Fig. 6). The c.f.u. continued to increase in number for a dose-dependent period before colony formation was inhibited. Inhibition of colony formation occurred sooner in cells irradiated with lower doses of UV light than in cells irradiated with high doses of UV light.

\section{DISCUSSION}

Experiments with the anaerobe $B$. fragilis on the effect of UV irradiation on DNA synthesis support the conclusion of Setlow \& Setlow (1970) that there is no unique best method for investigating macromolecular synthesis in irradiated bacteria. Rapid degradation of DNA immediately after UV irradiation of $B$. fragilis cells was only detected with prelabelled cells. This extensive degradation masked the discovery which was made with unlabelled cells that DNA synthesis was decreased, but never totally inhibited, by UV irradiation and continued during the degradation phase.

The characteristics of DNA synthesis in $B$. fragilis cells irradiated with far-UV light under anaerobic conditions differ from those reported for $E$. coli, where DNA synthesis is stopped completely and immediately by UV irradiation (Kelner, 1953; Swenson, 1976; Hall \& Mount, 1981). This inhibition of DNA synthesis in $E$. coli cells is dependent on a functional rec $A$ gene product (Trgovcevic et al., 1980). We previously reported that UV irradiation of $B$. fragilis cells 
did not result in the induction of a 37000 to 40000 molecular weight protein analogous to the recA protein in E. coli (Schumann et al., 1982). The discovery that UV irradiation under anaerobic conditions did not inhibit DNA synthesis supports our previous conclusion that $B$. fragilis cells do not have an $E$. coli rec $A$-type system.

Although some DNA degradation does occur in wild-type $E$. coli cells after UV irradiation it is limited (Swenson, 1976). Extensive 'reckless' DNA degradation occurs in recA mutants following UV irradiation (Clark, 1973). A similar extensive degradation of DNA after UV irradiation was observed in wild-type $B$. fragilis cells. In $E$. coli rec $A$ mutants this DNA degradation reflects the action of an uncontrolled $\operatorname{rec} B C$ DNAase (Williams et al., 1981). Rec $A$ protein and $\operatorname{rec} B C$ DNAase are not the only two enzymes involved in DNA degradation in $E$. coli. Excessive degradation following UV- or X-irradiation has been reported in ras, polA and uvrD mutants (Ogawa et al., 1968; Boyle \& Setlow, 1970; Youngs \& Bernstein, 1973). In these strains, 75 to $90 \%$ of the degradation is accounted for by recBC DNAase, with the remainder attributed to other nucleases (Youngs \& Bernstein, 1973). DNA degradation in E. coli rec $A$ mutants is greatly reduced by caffeine (Shimada $\&$ Takagi, 1967). Caffeine also inhibited DNA degradation in $B$. fragilis.

The inhibition by chloramphenicol of the extensive DNA degradation that occurs after UV irradiation in $B$. fragilis suggests that protein synthesis is required for degradation. In $E$. coli excision occurs in the presence of chloramphenicol (Swenson \& Setlow, 1966). Chloramphenicol reduced DNA synthesis in irradiated $B$. fragilis cells but did not inhibit it completely. Although chloramphenicol prevents the resumption of DNA synthesis in irradiated $E$. coli (Swenson, 1976), Swenson \& Setlow (1966) reported that in a radiation-resistant E. coli B strain DNA synthesis is resumed at the same time in irradiated cells with and without chloramphenicol. In Haemophilus influenzae X-rays induced degradation of DNA but the DNA breakdown was not inhibited by chloramphenicol (Stuy, 1961). DNA synthesis in irradiated $B$. fragilis cells treated immediately with chloramphenicol is analogous to stable DNA replication in $E$. coli in that it is an abnormal, UV-induced DNA synthesis which can occur in the absence of protein synthesis (Kogoma \& Lark, 1970, 1975; Lark \& Lark, 1978). However, B. fragilis differs from E. coli in that in $E$. coli protein synthesis is necessary during a $40 \mathrm{~min}$ period after irradiation before chloramphenicol addition for the initiation of stable DNA synthesis (Kogoma et al., 1979).

In $B$. fragilis colony formation was not inhibited immediately by $\mathrm{UV}$ irradiation and there was an inverse relationship between UV dose and inhibition of viability. An initial transient increase in colony formation after UV irradiation has also been reported in $E$. coli under conditions where DNA synthesis was inhibited in virtually all the cells (Okagaki, 1960; Smith, 1969). Smith (1969) observed that with both UV-sensitive and UV-resistant $E$. coli mutants there was an inverse relationship between UV dose and inhibition of colony formation.

These basic studies on $B$. fragilis provide a starting point for future work on UV repair and recombination in this important anaerobe. At present investigations are hampered by our inability to isolate UV-sensitive or UV-resistant mutants in spite of an extensive screening programme. Our results on the characteristics of DNA synthesis after UV irradiation and the difficulty experienced in isolating mutants in general in $B$. fragilis suggest that the UV repair and recombination systems in this anaerobe may differ from those in $E$. coli, which tend to be accepted as typical for bacteria in general.

J. P. S. acknowledges a postgraduate research bursary from the South African Council for Scientific and Industrial Research.

\section{REFERENCES}

Boyle, J. M. \& Setlow, R. B. (1970). Correlations between host-cell reactivation and pyrimidine dimer excision in the DNA of bacteriophage lambda. Journal of Molecular Biology 51, 131-144.

CLARK, A. J. (1973). Recombination deficient mutants of E. coli and other bacteria. Annual Review of Genetics 7, 67-86.

Hall, J. D. \& Mount, D. W. (1981). Mechanisms of
DNA replication and mutagenesis in ultravioletirradiated bacteria and mammalian cells. Progress in Nucleic Acid Research and Molecular Biology 25, 54126.

Holdeman, L. V. \& Moore, W. E. C. (editors) (1972). Anaerobe Laboratory Manual. Blacksburg: Virginia Polytechnic Institute and State University.

Hori, T., Ogawa, T. \& Ogawa, H. (1980). Organiza- 
tion of the recA gene of Escherichia coli. Proceedings of the National Academy of Sciences of the United States of America 77, 313-317.

JoNES, D. T. \& Woods, D. R. (1981). Effect of oxygen on liquid holding recovery of Bacteroides fragilis. Journal of Bacteriology 145, 1-7.

Jones, D. T., RoBB, F. T. \& Woods, D. R. (1980). Effect of oxygen on Bacteroides fragilis survival after far-ultraviolet irradiation. Journal of Bacteriology 144, 1179-1181.

KeLNER, A. (1953). Growth, respiration, and nucleic acid synthesis in ultraviolet-irradiated and in photoreactivated Escherichia coli. Journal of Bacteriology 65, 252-262.

Kogoma, T. \& LARK, K. G. (1970). DNA replication in Escherichia coli: replication in absence of protein synthesis after replication inhibition. Journal of Molecular Biology 52, 143-164.

Kogoma, T. \& LARK, K. G. (1975). Characterization of the replication of Escherichia coli DNA in the absence of protein synthesis: stable DNA replication. Journal of Molecular Biology 94, 243-256.

Kogoma, T., Torrey, T. A. \& Connaughton, M. J (1979). Induction of UV-resistant DNA replication in Escherichia coli: induced stable DNA replication as an SOS function. Molecular and General Genetics 176, $1-9$.

LARK, K. G. \& LARK, C. A. (1978). Rec $A$-dependent DNA replication in the absence of protein synthesis: characteristics of a dominant lethal replication mutation, dnaT, and requirement for $\operatorname{rec} A^{+}$function. Cold Spring Harbor Symposia on Quantitative Biology 43, 537-549.

Ogawa, H., Shimada, K. \& Tomizawa, J. I. (1968). Studies on radiation-sensitive mutants of $E$. coli. Molecular and General Genetics 101, 227-244.

OKAGAKI, H. (1960). Effect of chloramphenicol on the survival of Escherichia coli irradiated with ultraviolet light. Journal of Bacteriology 79, 277-291.

Sancar, A., Stachelek, C., Konigsberg, W. \& Rupp, W. D. (1980). Sequences of the $\operatorname{rec} A$ gene and protein. Proceedings of the National Academy of Sciences of the United States of America 77, 2611-2615.

Satta, G., Gudas, L. J. \& Pardee, A. B. (1979). Degradation of Escherichia coli DNA : evidence for limitation in vivo by protein $\mathrm{X}$, the $\mathrm{rec} A$ gene product. Molecular and General Genetics 168, 69-80.

Schumann, J. P., Jones, D. T. \& Woods, D. R. (1982). UV light induction of proteins in Bacteroides fragilis under anaerobic conditions. Journal of Bacteriology. 151, 44-47.

Setlow, R. B. \& Setlow, J. K. (1970). Macromolecular synthesis in irradiated bacteria. Mutation Research 9, 434-436.
Shimada, K. \& Takagi, Y. (1967). The effect of caffeine on the repair of ultraviolet-damaged DNA in bacteria. Biochimica et biophysica acta 145, 763770 .

Slade, H. J. K., Jones, D. T. \& Woods, D. R. (1981). Effect of oxygen radicals and peroxide on survival after UV irradiation and liquid holding recovery of Bacteroides fragilis. Journal of Bacteriology 147, 685687.

Slade, H. J. K., Schumann, J. P., Parker, J. R., JONES, D. T. \& WoODS, D. R. (1983). Effect of oxygen on host cell reactivation in Bacteroides fragilis. Journal of Bacteriology 153, 1545-1547.

SMith, K. C. (1969). DNA synthesis in sensitive and resistant mutants of Escherichia coli B after ultraviolet irradiation. Mutation Research 8, 841-850.

SMith, K. C. \& O'Leary, M. E. (1968). The pitfalls of measuring DNA synthesis kinetics as exemplified in ultraviolet radiation studies. Biochimica et biophysica acta $169,430-438$.

STUY, J. H. (1961). Studies on the radiation inactivation of microorganisms. VII. Nature of the X-ray induced breakdown of deoxyribonucleic acid in Haemophilus influenzae. Radiation Research 14, 5665

Swenson, P. A. (1976). Physiological responses of $E$. coli to far-UV radiation. In Photochemical and Photobiological Reviews, vol. 1, pp. 269-387. Edited by K. C. Smith. New York: Plenum Publishing Corp.

Swenson, P. A. \& Setlow, R. B. (1966). Effects of ultraviolet radiation on macromolecular synthesis in Escherichia coli. Journal of Molecular Biology 15, 201219.

Trgovcevic, Z., Petranovic, D., Petranovic, M. \& SALAJ-Smic, E. (1980). RecA gene product is responsible for inhibition of deoxyribonucleic acid synthesis after ultraviolet irradiation. Journal of Bacteriology 143, 1506-1508.

VAREL, V. H. \& BRyant, M. P. (1974). Nutritional features of Bacteroides fragilis subsp. fragilis. Applied Microbiology 28, 251-257.

Willetts, N. S. \& ClaRK, A. J. (1969). Characteristics of some multiple recombination-deficient strains of Escherichia coli. Journal of Bacteriology 100, 231-239.

Williams, J. G. K., Shibata, T. \& Radding, C. M. (1981). Escherichia coli recA protein protects singlestranded DNA or gapped duplex DNA from degradation by recBC DNase. Journal of Biological Chemistry 256, 7573-7582

Youngs, D. A. \& Bernstein, I. A. (1973). Involvement of the rec $B$-recC nuclease (exonuclease $\mathrm{V}$ ) in the process of X-ray-induced deoxyribonucleic acid degradation in radiosensitive strains of Escherichia coli. Journal of Bacteriology 113, 901-906. 